\title{
THE POLITICAL CONSTRUCTION OF EXTRACTIVE REGIMES IN TWO NEWLY CREATED INDIAN STATES: A COMPARATIVE ANALYSIS OF JHARKHAND AND CHATTISGARH
}

\begin{abstract}
This article presents a multidimensional account of the politics of resource extraction in two subnational regions of India in response to the question: what are the political conditions that facilitate extraction? Emerging from the same moment of state creation in 2000, Jharkhand and Chhattisgarh are adjacent mineral-rich states with similar demographic profiles and comparable levels of economic development. The article argues that despite these similarities and India's highly centralised legislative framework for natural resource governance, the two states have developed distinctive 'extractive regimes' in the years since statehood, which have important contrasts across three dimensions; political organisation and history, institutional effectiveness and the nature and management of social resistance. It offers the first in-depth, comparative account of how subnational territorial reorganisation in India acts as a critical juncture enabling the formation of extractive regimes, which have also converged in important ways in recent years.
\end{abstract}

\section{INTRODUCTION}

The creation of the two mineral rich states of Jharkhand and Chhattisgarh in November 2000 in eastern and central India was profoundly significant for the politics of extraction in this country. Subnational territorial reorganisation had thrown up important questions of control over subsoil mineral resources for the states' large indigenous (Adivasi or tribal ${ }^{1}$ ) populations (Mawdsley, 2002; Tillin, 2013). The political elites of these newly created states committed to the idea of development fuelled by these rich resources, which had previously been appropriated for other regions in the parent states of Bihar and Madhya Pradesh (Mullick, 2011).

Moreover, state creation occurred at a time of intensified economic deregulation, following the introduction of economic liberalisation in 1991, which has seen states across India competing to attract private capital in lucrative areas like infrastructure development and mining (Corbridge, 2011). The role of the central government has remained critical, from the introduction of new laws to enable and facilitate expanded private sector involvement, to changing the rules of the

\footnotetext{
${ }^{1}$ Adivasis refer to the indigenous peoples of India, who are also broadly described as tribal and categorised as the Scheduled Tribes within the Constitution. We will use 'adivasi' and 'tribal' interchangeably in this article.
} 
game on vital issues like coal block allocation and managing political pressures for dealing with discontent around land acquisition. Resistance around mining has only intensified, creating effective deadlock in many sites, even as the 'rich land, poor people' paradox has persisted (CSE, 2008).

However, despite a dominating centre that structured the legal and institutional landscape of extraction, and some seriously worrying national level trends (like large scale land dispossession), the experiences of Jharkhand and Chhattisgarh in the nearly two decades since 2000 in facilitating extraction have been far from similar. Their remarkably comparable human development profiles, but drastically different political configurations, have exposed the limits of 'resource curse' type explanations. Instead, these have generated questions about the critical juncture of state creation for the ideological, political, social and institutional conditions that ensued, making extraction possible. These come at a time when there is an energetic debate underway both internationally (Bebbington et al, 2018), and within India about the significance of subnational variations in the conditions that facilitate extraction, or more broadly, dispossession (Levien, 2015, 2018; Sud 2014).

In the rest of this article, we make a case for the need to theorise these larger social, economic and political conditions, which drive the discursive and institutional apparatus of the state in these newly created mineral rich states as 'extractive regimes'. We then present an original and in-depth analysis of the extractive regimes that developed at statehood, while also contrasting Jharkhand and Chhattisgarh, and discerning convergences. The article draws on research over four years (2014-2018), with extended primary work in the two states, involving about 110 interviews with informants from government, industry, civil society and the media at both state and district levels, and a range of secondary sources, including policy and legal documents, election manifestoes, government and industry reports, $\mathrm{RTI}^{2}$ information and the news media.

\section{FRAMING THE PROBLEM: THE POLITICS OF EXTRACTION AND SUBNATIONAL TERRITORIAL REORGANIZATION IN INDIA}

\footnotetext{
${ }^{2}$ The Right to Information (RTI) Act of 2005 allows citizens to file information requests on aspects of governance, which the state is legally bound to respond to.
} 
Scholars writing on the politics of extraction have challenged the hegemony of the "resource curse' paradigm (Ross, 2015) in a number of ways. This follows criticisms that the 'curse' has a deterministic tone to it and attention must be paid to understanding its 'complexities and conditionalities' (Papyrakis, 2017). As debates have advanced, scholars have called for liberation from the 'narrow question of whether there is a curse' (Ross, 2015: 253), and for recognition of the diversity of possible outcomes from extractive development (Bebbington et al., 2008).

A major area of critical scrutiny has been the focus on institutional quality within this paradigm, with scholars pointing out that institutional change has political drivers (Bebbington, 2013, Bebbington et al., 2018, Di John, 2009). They have tried to understand the political coalitions and ideas shaping the origins, formation and concrete workings of institutions (Bebbington et al., 2018; Potetee, 2009; Hickey and Izama, 2017). And yet, the political analysis of extraction is not limited to challenging the resource curse paradigm alone, as it also presents multiple new ways of conceptualising the political dynamics around extraction (see, for example, Karl, 1987, 1997 on the significance of elite pacts about the use of extractive rents; Watts, 2004 on the reconfiguration of the Nigerian 'petro state'; Bebbington, 1996 and Horowitz, 2012 on the political strategies of activist groups).

Unlike the resource curse literature, the scholarship on the politics of extraction does not focus primarily on the consequences of extraction, and of 'extractivism' as economic policy. Arsel et al have discussed the extractive imperative as a 'deepened, broadened and self-sustained form' which provides an ideological basis for states to promote extractive activities (2016: 881). Various scholars have argued that extractive activities require the coordinated and wilful effort of a large number of stakeholders and actors at different levels (Watts, 2004; Bebbington, 2012; Bridge, 2013; Arsel et al, 2016; Marston and Perreault, 2017 amongst others).

The resource curse literature has been criticised for the domination of cross-country research methods, the fragmentation of 'scale and methodological and policy focus' and an inadequate exploration of multi-scalar issues (Gilberthorpe and Papyrakis, 2015: 383; Papyrakis, 2017). In response, scholars have persuasively argued that the focus on resources accords a centrality to questions of place, scalar relations and time to the study of politics and institutional change (see 
Bebbington, 2013; Humphreys-Bebbington and Bebbington, 2012; Bebbington et al, 2018 amongst others). This necessarily throws up questions around multilevel dynamics, which are now receiving much more attention across mineral rich countries. A good example is Latin America, where the focus has been on the overarching extractive economy, the role of the national state as well as transnational actors, but this is now changing with growing interest in the subnational level for several important reasons (see Anthias, 2018; Bebbington et al, 2018; Bridge, 2004; Porter and Watts, 2016). The dynamic configurations of power wielded by subnational actors is a running theme across the scholarship.

India presents a particularly interesting case for pursuing multilevel research around the politics of extraction. It is a mineral rich country with a high global rank in major minerals production $\left(3^{\text {rd }} \text { for coal, } 4^{\text {th }} \text { for iron ore }\right)^{3}$. However, its national economy is far from dependent upon mining (the contribution of mining to GDP was 1.2\% in both 2000 and 2010; for comparison, in other mineral-rich countries, like Chile and South Africa, this figure was 6\% and 5.3\% in 2010 respectively) (Chakraborty, 2016). This suggests that typical 'resource curse' problems associated with a high level of economic dependence on mineral resources (like Dutch Disease, macroeconomic volatility) may not necessarily be observed in the same way here (Papyrakis, 2017). Subnational units or states have ownership and royalty rights over subsoil minerals, but the national government continues to have final say in a number of critical spheres (setting of royalty rates, allocation of coal mines, and regulation of environmental clearances amongst others). Like other economic sectors, mining too has been liberalised, with 100\% FDI since 1993. Transnational actors like Vedanta and POSCO have made their presence felt, often stirring intense resistance (Kumar, 2014). However, the relatively small role of foreign capital overall in the extractives sector ${ }^{4}$ suggest that debates around foreign actors do not necessarily translate into questions of sovereignty, as they might do in other countries. Although state-ownership has dominated coal mining, the space for private domestic capital is slowly expanding, with several

\footnotetext{
${ }^{3}$ Annual Report 2013, Ministry of Mines, Government of India cited in http://www.ey.com/Publication/vwLUAssets/Mining_in_Emerging_Economies/\$FILE/EY-Mining-inEmerging-Economies.pdf

${ }^{4}$ One indication is that large scale expropriation of land in India is primarily done by domestic capital both public and private rather than foreign capital (Sampat, 2010 as cited in D'Costa and Chakraborty, 2017).
} 
key concessions being made to the private sector in the mining of this heavily protected mineral since 1991 (see Section 4 for more details). Moreover, since 1991, Coal India Limited (CIL), the government run coal monopoly has increasingly involved the private sector through various forms of contracting (Chandra, 2018). The share of private capital investment is higher in the mining of certain minerals. For instance, the private sector contributes to nearly $2 / 3$ rds of the total iron ore production in the country ${ }^{5}$ such as iron ore.

In India, mining (particularly coal) has consistently been equated with national economic development (see Lahiri-Dutt, 2014a) ${ }^{6}$. In 2014, the contribution of mining to the national economy was valued at $\$ 33$ billion (GoI, Department of Mines Annual report 2013-14). Mineral extraction has been prioritised by national and subnational political leaders alike. In this context, the creation of two new mineral rich states in 2000 is significant for its promise of a new and intensified politics of mineral extraction. Territorial reorganisation has enabled the "territorial projects' of important political actors, and as this article argues, has allowed them to construct and govern the newly created spatial-political entities in ways that are compatible with their political-ideological concerns as well as political coalitions (apropos Bebbington et al, 2018).

\section{[INSERT Figure 1]}

The territorial map of India has changed a number of times since 1947, the latest being in December 2013. Since the mid-1990s, the demand for the creation of smaller states has been expressed in terms of administrative and fiscal efficiency, improved and more accountable governance, and substantively greater political representation for indigenous minorities (Mawdsley 2002, Tillin 2013). In addition, Jharkhand and Chhattisgarh enjoyed concentrations of key natural resources like forests and mineral wealth ${ }^{7}$. Control over resources for the benefit

\footnotetext{
${ }^{5}$ Indian Bureau Mines, Government of India, Statistical Profiles (2017-18)

${ }^{6}$ Justified by the growing energy demands of a large populous and industrialising economy, and the appeal of renewables, coal remains fundamental to the Indian economy (IEA, 2015).

${ }^{7}$ Chhattisgarh has the third largest area under forest cover in the country. $41 \%$ of the state's total geographical area is covered by forests compared to 30\% in Jharkhand (Forest Survey of India 2013). It is also the second largest producer of iron ore after Odisha followed by Jharkhand. Chhattisgarh is the
} 
of poor adivasi populations featured prominently in the demand for statehood. This was especially the case in Jharkhand, a state with more than half a century of tribal social movements, several of which campaigned against forest and land alienation (Singh, 2008; Tillin, 2013). In Chhattisgarh, this was less so. Incoming political elites in both espoused similar ideas around modernisation and industrialisation, which have been subsequently developed in an array of 'Vision' documents (Jharkhand's Vision 2010 and 2020, Chhattisgarh's Vision 2010 and $\left.2022^{8}\right)$.

Both states pursued extraction with the mining sector contributing approximately $10 \%$ of the state's GDP over the years (2004-2014) (Chakraborty, 2016). Mining activity in both has been comparably vigorous; land area leased for major minerals in Jharkhand and Chhattisgarh was 27067 and 22302 hectares in 2014 . In 2013-14, Chhattisgarh and Jharkhand produced 127 and 113 million tonnes of coal, and 28 and 18 million tonnes of iron ore respectively ${ }^{10}$. Moreover, their economic status is fairly similar, with both states lagging behind in critical human development indicators (see Table 1). Most of their mining districts (6 out of the top 7 in Chhattisgarh, and all but 2 in Jharkhand) feature in the list of 150 "most backward districts" in the country (Centre for Science and Environment, 2008). Viewed from a 'resource curse' perspective, both states present a fairly similar picture, but this obliterates from consideration the profound differences in the ways that extraction is pursued.

\section{[INSERT Table 1]}

Understanding how extraction, which causes much social dislocation, is facilitated and managed under two distinctive subnational political domains is the problem that motivates this article. India is an established multiparty democracy with a powerful centre and a range of subnational settings. How did subnational territorial reorganisation produce the political, ideological and

biggest contributor to coal production in the country followed by Jharkhand (Ministry of Coal, 2013; Indian Bureau of Mines, 2013).

${ }^{8}$ http://unpan1.un.org/intradoc/groups/public/documents/APCITY/UNPAN011834.pdf; http://www.ibef.org/download/IBEF_CHHATISGARH_260508.pdf; http://indiainbusiness.nic.in/newdesign/index.php?param=statesinfo/23/709/1

${ }^{9}$ www.ibm.nic.in

${ }^{10}$ Indian Bureau of Mines, Statistical Profiles 2013-14 and Provisional Coal Statistics, Ministry of Coal 2013- 14 
institutional conditions that facilitated extraction in Jharkhand and Chhattisgarh? To what extent were these similar or different? What was the nature of the 'extractive regime' that developed in each state, what were the most important dimensions of such a regime, and what results did these dimensions produce? The article seeks to make an original contribution in presenting the first indepth account of the subnational politics of extraction stemming from territorial reorganisation in India.

\section{THEORISING THE EXTRACTIVE REGIME}

A good place to start while theorising the extractive regime is that of the 'resource regime': "territorialised complexes of political economic institutions, socio-natural relations, which support particular forms of resource extraction, and the interests of those involved, over an extended period of time" (Marston and Perreault 2017, 256; Bridge, 2013). There have been more specific applications of this notion, like 'forestland regimes' connoting the 'configuration of actors, authorities and institutions that regulate forest and land use, as well as "the formal and informal structure and nature of political power" in forested regions' (Kashwan, 2017, 4).

In India, there is no explicit theorisation of the extractive regime till date, while mineral extraction is politically significant, with its antecedents nested deep within national economic development. And yet, there is a clear need to explain how extraction is pursued within democratic settings despite high costs, and resistance from an active civil society. The problem of land acquisition for a variety of purposes, including extraction, can offer a starting point. While dispossession for development stems right back to the Nehruvian era after independence (Ray and Katzenstein, 2005), deregulation and subnational competition for economic investment in the post-liberalisation era have shaped how states within India orchestrate land acquisition for industry (Levien, 2013, 2015 and 2018; Sud, 2014, Bo Nielsen and Nilsen, 2017; and D'Costa and Chakraborty, 2017).

Building upon Harvey's (2003) well known thesis, 'accumulation by dispossession', Levien has effectively argued that state led dispossession is a feature of fully developed capitalism. The state has created the conditions whereby it acts as an 'owner, intermediary, buyer and distributor' all 
into one (D'Costa and Chakraborty, 2017). It has legitimating mechanisms like the recently enacted LARRA $2013^{11}$, labelled a 'compromise equilibrium', ultimately intended to facilitate India's process of neo-liberalisation (Bo Nielsen and Nilsen, 2017; Levien, 2018). This duality of purpose, where states compete to provide concrete incentives for the ease of acquisition of land to private investors on the one hand, and pursue generous compensation and rehabilitation policies meant to appease influential farming groups on the other, marks the new era of 'broker' states within India (Levien, 2018; Sud, 2014). While an in-depth discussion of this literature is beyond the scope of this study, it is useful to draw out: a) the modalities of this 'regime of dispossession', and b) the actors and agencies that make up the regime.

Levien and Sud, in different ways, characterise the modalities of what Levien has captured as a 'regime of dispossession'. Levien (2018) lays down a broad comparative framework to regard how socially and historically distinct regimes arise: the first is the institutionalisation of state mechanisms to expropriate land from users, which are tied into particular class interests; the second is the political authority to make people comply with state orders, whether through coercion, compensation or persuasion; and the third is the public legitimacy of the regime of dispossession which directly impacts upon its stability and durability. In contrast, Sud (2014)'s emphasis is more specifically aimed at how regimes work, including the generation of legitimating ideas by state officials, their direct brokerage in favour of land expropriation, and, their actions taken to dissipate protests. Moreover, Sud's argument that India's states are not 'pro-market', but 'pro-business', describes the deep embeddedness and personal ties between politicians, bureaucrats and private business players, which unfold in the context of an often unscripted and chaotic state 'strategy' for land dispossession.

The regime of dispossession enrols a multitude of state actors and agencies at different levels. These primarily include state level government agencies or parastatals (like the industrial development corporations and urban development authorities) and government departments like Industry and Mines that play proactive enabling roles, while accruing 'unofficial rents...that make the License-permit-quota Raj look quaint' (Levien, 2018: 54). Reports of discretionary

\footnotetext{
${ }^{11}$ The rather lengthily titled Right to Fair Compensation and Transparency in Land Acquisition, Rehabilitation and Resettlement Act, 2013.
} 
treatment both by the Ministry of Environment and Forests at the centre, as well as the State Environmental Impact Assessment Authorities abound (Ghosh, 2006). Lastly, much mention is made of the pliancy of courts, also at different levels (Bo Nielsen and Nilsen, 2017).

While these insights are critical for understanding the composition and orientation of the regime that dispossesses, there is still scope to go further in terms of offering a deeper political explanation of how extraction becomes possible in similar, yet different political conditions, and whether these contrasts matter. The context of territorial reorganisation provides a valuable opportunity to observe statehood as a critical political, institutional and ideological juncture, shaping the political conditions for extractive development, while also allowing for an assessment of the legacy effects of the parent states. Based on this unique context, this article seeks to theorise the extractive regime by asking three questions.

We respond to and extend some of the arguments discussed here to ask how the organisation of political competition matters for the political leadership's public commitment to extraction and what kinds of historical and political factors contribute to making the extraction of minerals politically salient within public discourse? Second, while scholars such as Levien and Sud show that politicians everywhere try to attract investors and facilitate extraction, they do not comparatively consider whether the political enablement of state (or bureaucratic) capacity actually matters for how effectively extraction is pursued. Institutional effectiveness relating to extraction is defined specifically here from the viewpoint of the extractive industry, in terms of enablement and expediting, as opposed to securing greater rights for those divested of resources and rights. Third, building on recent scholarship which emphasises that the ability of the state to execute dispossession depends vitally on the balance of political forces (Levien 2018), this article asks how political conditions differ in actually shaping state management of resistance to extraction becomes salient.

The three dimensions of the 'extractive regime' that we postulate, will then be used to compare and contrast Jharkhand and Chhattisgarh, including a discussion of the results that are produced. A stylised table of the dimensions of comparison is presented below. 
[INSERT Table 2]

\section{CHANGING CONTEXT OF EXTRACTIVE RESOURCE GOVERNANCE IN INDIA}

Given the well-articulated imperative around the use of subsoil resources for national development after independence (Lahiri, 2014a), it was unsurprising that the centre retained a firm control over mining. The Mines and Minerals Development and Regulation Act (MMDR), 1957, gave the central government exclusive law-making power over the regulation and development of major minerals in the country ${ }^{12}$, with a division of implementation responsibilities. The Coal Bearing Areas (Acquisition and Development) 1957 Act, allowed the centre 'the power of eminent domain' for land acquisition to facilitate coal mining. Other central laws like the colonial era Land Acquisition (Mines) Act, 1885, and the Land Acquisition Act, 1894, and more recently, the LARRA, 2013, set out the legal infrastructure around various aspects of extraction. However, states have additional laws around acquisition and compensation. Both Jharkhand and Chhattisgarh, with large tribal populations and scheduled areas (governed under the $5^{\text {th }}$ schedule $)^{13}$ have stringent laws governing and restricting the sale of lands.

However, the adoption of economic liberalisation in 1991 led to a marked shift, with the allowance of up to $100 \%$ FDI in mining following the new mineral policy of 1993. Further enabling measures to encourage foreign investment were introduced in later years, like the automatic approval route for investments involving foreign equity participation up to $50 \%$ in mining projects, and up to $74 \%$ in services incidental to mining. India, despite its high global position in mineral production has proved challenging for investors, with its quagmire of opaque regulations, poor infrastructure and the competition for land usage, amongst other factors. Newer 'frontier' markets in Latin America remain more attractive in comparison ${ }^{14}$.

\section{[INSERT Figure 2]}

\footnotetext{
${ }^{12}$ Defined under Schedule I of the MMDR Act and includes coal, iron ore and bauxite.

${ }^{13} \mathrm{https}: / / w w w . m e a . g o v . i n / I m a g e s / p d f 1 / \mathrm{S} 5 . p d f$

$14 \mathrm{https}$ :/www.ey.com/in/en/industries/mining---metals/ey-emerging-economies-and-indias-miningindustry
} 
(Source: Ministry of Commerce and Industry, Department of Industrial Policy and Promotion)

Another important development is that the private sector was allowed to engage in the exploitation of 13 major minerals (including iron ore and bauxite). Coal was the exception, following the Coal Areas Nationalisation Act of 1973, but in 1993, private sector participation was allowed in captive coal mining as well. In 2015, the Coal Mines (special provisions) Act was passed, which removed the restriction of end use from the eligibility of private actors to undertake coal mining except in the case of certain specified coal blocks ${ }^{15}$. In 2018 , the central government ended the 45-year monopoly of Coal India Limited by opening up commercial coal mining for the private sector in the interests of efficiency, productivity and competitiveness ${ }^{16}$. These developments resonate with the creation of subnational 'competition' (Corbridge, 2011) or 'broker' states (Levien, 2018) that try to outdo each other attracting investors. As a result, there has been the consistent growth of the private sector's involvement in both major and minor minerals across India. Overall mineral production has increased in absolute terms after the economic reforms of the 1990s. The total value of mineral production between 1991 and 2011 increased from less than $\$ 1$ billion to $\$ 31$ billion for fuel and metallic minerals (Indian Bureau of Mines).

Within this changing context of resource governance, states continue to depend upon central directives in a number of critical areas. These range from the regulation of illegal mining (like with the Shah Commission that published its report in 2013 or the Supreme Court's cancellation of mining leases in Karnataka in 2013), or the shift from allocation to auction of coal blocks by the central Coal Mines (special provisions Act of 2015). The inherently multilevel and nested nature of resource governance in the extractive sector nevertheless allows for very distinctive subnational domains within which extraction is pursued.

\section{THE CREATION OF MINERAL RICH JHARKHAND AND CHHATTISGARH}

\footnotetext{
${ }^{15} \mathrm{http}: / /$ pib.nic.in/newsite/PrintRelease.aspx?relid=117513

${ }^{16} \mathrm{https}$ ://coal.nic.in/content/commercial-coal-mining-private-sector
} 
While India has a number of mineral rich states (Karnataka, Odisha, Andhra Pradesh), Jharkhand and Chhattisgarh are exceptional in that they are the only two mineral rich states whose existence is owed to recent subnational reorganisation. After bifurcation in 2000, Jharkhand acquired control of most deposits relative to its parent state Bihar, and while Chhattisgarh has a large share compared to Madhya Pradesh (MP), the latter still retains considerable mineral resources (Dhillon et al, 2016). The average contribution of mining to the state GDP in both Jharkhand and Chhattisgarh has been consistently around 10\% between 2004-05 and 2013-14 (Chakraborty, 2016). Other mining states have stayed well below this. As for the parent states after 2000, mining has contributed to a meagre $0.1 \%$ of GSDP in Bihar throughout, whereas in MP this figure was 5\% in 2004-5 and has dropped steadily to 3\% in 2013-14 (Chakraborty, 2016).

There were important differences in the socio-political dynamics related to the extractive industries in Bihar and MP, before bifurcation. These shaped the major actors that would assume prominence in the extractive sectors of the newly created states as well as their mutual relationships. Politics in Bihar had been dominated by the upper castes since independence, but this changed with the increased prominence of lower castes from the 1970s onwards (Robin, 2009; Kale and Mazaheri, 2014). The high-caste led Congress party, in power for long periods in the 1970s and 1980s, nurtured a close relationship with the politically important coal sector, and, in particular, the Tata Company (ibid.). The coal sector was also home to a local alliance of politicians, contractors, mine officials, trade union leaders as the formidable 'coal mafia', which accumulated vast amounts of wealth (Bhattacharjee, 2017).

In the 1970s and 1980s, Congress chief ministers handed out various waivers and benefits to elite private industrial houses, foremost among which were the Tatas. The Tatas for instance, were allowed to circumvent a law which required the payment of a tax for education and agricultural development. This implicit waiver amounted to millions of dollars but the figure was downplayed by the Congress leadership ${ }^{17}$. When Laloo Yadav came to power in 1990 with the strength of a formidable lower caste mobilisation to back him, his government dedicatedly sought to shrink the influence, incomes and political reach of the upper castes. One of these was

\footnotetext{
${ }^{17}$ Kale and Mazaheri (2014) offer more details in their paper.
} 
to actually keep posts vacant, effectively creating 'state incapability by design' (Matthew and Moore, 2011), and the other, was to hurt the privileged position of key industrial and mining actors like the Tatas (Kale and Mazaheri, 2014) ${ }^{18}$. This 'strategy' was reflected in an economic downturn within the mining and heavy industry sector in Bihar (Chakravorty 2003). Royalty payments from coal mines from 1991-92 to 1999-2000 rose in all coal mining states, but this was less in Bihar in comparison (it registered a rise of $75.9 \%$ compared with $181 \%$ in Madhya Pradesh) (Kale and Mazaheri, 2014) ${ }^{19}$.

There were two clear implications of this history for Jharkhand. One, there was an 'automatic adoption of Bihar's industrial policies in Jharkhand ${ }^{20}$. Given the state of decline of industry in the last decade under Laloo, this was clearly a bad start for the extractive sector. Two, statehood provided a clear break from Laloo's politics, and an opportunity for the Tatas and other industrial houses like Usha Martin to develop close relationships with the incoming political leadership and the bureaucracy. The Tatas assumed a hegemonic posture in the new state, asserting a strong sense of belonging. 'There can no bigger Jharkhandi than the Tatas, we have been here for over 100 years', said an official ${ }^{21}$. As the mining sector across India opened up to the private sector, it was mostly 'outside capital' from other parts that came in, as 'insiders' did not really have the access to the capital needed. Over the years, companies including Electro Steel, Jindal Steel and Power Limited, Rungta and Essar, have established themselves. So-called 'outsider' involvement has provided political ammunition to leading adivasi parties like the JMM to rally against moolvasis, a historical label associated with the non-adivasi entrants to the region.

In MP, politics was considerably different in the 1990s, and in fact, both leading parties (Congress and the BJP) have remained firmly upper caste dominated right until the creation of Chhattisgarh, and beyond (Jaffrelot, 2009). With the increasing mobilisation of the OBCs in the post-Mandal years, both parties tried to follow a policy of appeasement of the OBC elites (more

\footnotetext{
${ }^{18}$ Laloo made the Tatas pay for the use of the waters of the river Subarnarekha in Jamshedpur, for instance, even as the Tatas tried to cultivate goodwill by building a hospital in Patna, the capital of undivided Bihar (Email exchange a retired civil servant, February 2019).

${ }^{19}$ Data originally from www.indiastat.com

${ }^{20}$ Interview, industry department official, Ranchi, 2014.

${ }^{21}$ Interviews in Ranchi, 2014.
} 
the BJP) (ibid.). The creation of Chhattisgarh in 2000 was seen as a nod to the growing political mobilisation amongst the OBCs in that region (Tillin, 2013), though in the new state too, OBCs were subsumed within the main national parties. OBCs made up 39-40\% of the population of the new Chhattisgarh (see Berthet, 2011).

Moreover, unlike Laloo's Bihar where much of the decade was spent unravelling industrial progress $^{22}$, MP had steadily built a solid legacy of several large public sector undertakings or PSUs (like the Bhilai Steel Plant, established in 1955, and others including NTPC and BALCO). Amongst other benefits like the growth of townships, PSUs contributed to the 'creation of a Chhattisgarhi middle class, whereas earlier everyone that was affluent, was an "outsider" in some sense ${ }^{23}$. This was a reference to the waves of upper caste arrivals (Rajputs, Banias and Marwaris) from other states like Haryana and Rajasthan. They went on to dominate not only commerce and industry in the state, but also politics.

Public sector led industrialisation since the 1950s and 1960s, morphed into the 'second wave' of post-1993 industrialisation, and MP experienced a growth in investment in the heavy industry sector (Kale and Mazaheri, 2014). Once Chhattisgarh was created, this process continued seamlessly, with mining registering a spurt following the spectacular rise in demand for iron ore in China in the 2000s. Many private actors entered, including both older favoured players like Jindal Steel and Power Limited, and newer ones like Monnet and Prakash Industries, and later the Adanis and Reliance. While many of these actors were pan-national, it is also the case that the growth of industry in Chhattisgarh has found local support within the wealthier, higher caste business community. Ever since the BJP came to power in 2003, its core constituency included the traders, who have fielded a number of successful politicians.

\section{THE EXTRACTIVE REGIMES OF JHARKHAND AND CHHATTISGARH}

This section substantiates the three dimensions of the extractive regime in these two states: political history and organisation, institutional functioning, and the management of resistance.

\footnotetext{
22 Jharkhand also inherited some important PSUs like the Bokaro Steel Plant.

${ }^{23}$ Interview, local lawyer and activist, Bilaspur, 2015.
} 


\section{Political History and Organisation}

The formation of Jharkhand was preceded by more than half a century of tribal social movements and the nurturing of a clear tribal political identity (Corbridge, 1987, 2002; Basu, 2012; Tillin, 2013). This was set in the context of the arrival of waves of non-tribal dikus, largely Hindu upper castes from the plains, since the early 1900s. Ethno-centric subnational identity and resource-based agitations were integral elements of the early years of the statehood movement (Basu, 2012). Foremost amongst the many tribal political organisations that arose in the 1960s and 1970s was the Jharkhand Mukti Morcha (JMM) that was hailed as India's 'first Red Green Movement' for bringing the interests of trade unions and adivasis together (Omvedt, 1993). Eventually, the statehood movement and the JMM, which had to appeal to a broader coalition of tribals and non-tribal residents (moolvasis) to preserve its electoral base, had to create a new political discourse around regionalism instead of ethnicity (Damodaran, 2006; Tillin, 2013).

The Bharatiya Janata Party (BJP) took this further by promoting a version of cultural nationalism, which subsumed adivasi interests within a majoritarian form of recognition politics and further de-linked the demand for statehood from adivasi identity. In the end, Jharkhand was born of a complicated political battle and deals struck between the leadership at the centre and the parent state of Bihar. The BJP's vision for the state was centred on the 'proper utilisation' of south Bihar's (now Jharkhand) natural resources. Babulal Marandi (BJP), the state's first Chief Minister (CM), proclaimed, 'The era of development has started. Agriculture cannot sustain us. We have to enter into business and for that we need land and capital' (Mullick 2011, 393). The newly created Jharkhand also witnessed the emergence of a large number of adivasi parties, each claiming to be the genuine inheritor of the legacy of the Jharkhand movement, though indistinguishable in reality.

Despite the dilution of the tribal cause in the immediate events of statehood, the idea of Jharkhand as a 'homeland for tribals' has endured both politically and in popular memory (Tillin, $2013,95)$. For instance, the battle over a domicile policy raged on for years post state formation because of contentious and often violent disagreement over the definition of a "real Jharkhandi". 
More recently, the JMM's quick call to action to protest the February 2019 order of the Supreme Court to evict 1.89 million tribals from the forests, prompting the ruling party to respond ${ }^{24}$, is another indication that tribal identity continues to be politically charged in Jharkhand.

The legacy of statehood has made it tricky for Jharkhand's political leadership to strike an appropriate political discourse about extractive development for much of the time since 2000. Hemant Soren of the JMM, currently the leader of the opposition said ${ }^{25}$, "We are not against the fact that industry should be there. They have to be there, but in a way that people should feel that they are still the maalik (owners)". Jharkhand has witnessed extreme fragmentation of political competition, with various different combinations of adivasi parties in power between 2000 2014. Through the 13 successive changes in government in this period ${ }^{26}$, "There was no political backing for land acquisition for industry, and this is why we do not get any clarity in the orders we receive from government". Levien (2018) points to a similar imbroglio at the national level, with difficulties in balancing the land requirements of neo-liberal capitalism with the increasing political salience of land and farmer demands.

The irony however is that extractive activity has continued under the rule of adivasi parties including $\mathrm{JMM}^{27}$, without any credible backing of alternative resource governance policies that protect tribal rights. Nonetheless, the political history and organisation of Jharkhand's extractive regime is strongly characterised by its legacy of the statehood movement and subsequent proliferation of adivasi parties vying for predominance with the BJP. This has meant that the question of whether the newly formed state is serving the interests of adivasis or not, spurs activists and political elites alike. JMM's own social base has been changing; a Lokniti-CSDS survey showed fewer adivasis, and more upper castes and OBCs voting for the party over 20002014. In 2014, the BJP- which commands the dominant vote share of the upper castes and the

\footnotetext{
${ }^{24} \mathrm{https}$ ://www.business-standard.com/article/news-ians/jharkhand-to-file-review-petition-against-scorder-to-remove-tribals-from-forest-land-119022500991_1.html

${ }^{25}$ Interview, Ranchi, July 2015.

${ }^{26}$ Interview, Industries Department Official, Ranchi, December 2014

${ }^{27}$ Indeed, Jharkhand's adivasi leaders made tremendous personal profits from MoUs signed with mining companies, some even landing serious corruption charges (Vaishnav, 2017).
} 
OBCs in Jharkhand ${ }^{28}$ - finally won a majority and appointed a non-tribal (Raghubar Das) as CM for the first time in history.

The steady stay in power of a pro-extraction party has accelerated the political commitment to extraction, resulting in some important concrete changes like the amending of the 1908 Chota Nagpur Tenancy Act to allow the acquisition of tribal land for mining and industry in $2016^{29}$. The state appears to be at the crossroads now. On the one hand, it is still difficult to overturn the political discourse stemming from the state's long and complex tribal legacy ${ }^{30}$, but equally, on the other, there is a worrying increase in state sponsored violence and manipulation to facilitate land acquisition for mining (more in the next section) ${ }^{31}$.

Unlike Jharkhand, Chhattisgarh had no distinctive popular movement demanding statehood (Berthet, 2011; Tillin, 2013). The idea of statehood can be traced to political mobilisation amongst the dominant $\mathrm{OBCs}$ or middle peasantry who managed to evince interest amongst Congress party leaders (Tillin, 2013). Other important political actors like the Chhattisgarh Mines Shramik Sangh (Workers Union) and the Chhattisgarh Mukti Morcha (Liberation Front) did rally the peasantry and workers to demand statehood, but lost out in political salience in the eventual run up (Berthet, 2011). The presence of a distinctive cultural Chhattisgarhi identity derived from agrarian folk culture is widely acknowledged ${ }^{32}$. But unlike Jharkhand, there is only a tenuous link here between resource politics and tribal identity.

Following on from the legacy of the parent state (MP), and the absence of any comparable adivasi political mobilisation unlike Jharkhand, Chhattisgarh has experienced stable bi-party

\footnotetext{
${ }^{28} \mathrm{We}$ are grateful to Lokniti-CSDS for sharing their survey data.

${ }^{29} \mathrm{http}$ ://www.hindustantimes.com/ranchi/jharkhand-commercial-use-of-tribal-land-gets-cabinetapproval/story-DZhxiSsHkFJv0hmhglXFFL.html

${ }^{30}$ An NGO worker in Ranchi remarked that even when BJP CM Raghubar Das talks about promoting mining in public rallies, he feels the need to preface it with the supremacy of tribal rights (Informal exchange, Ranchi, August 2016).

${ }^{31} \mathrm{https}$ ://www.indiaspend.com/taking-over-fertile-land-for-adani-group-from-protesting-farmersjharkhand-government-manipulates-new-law-meant-to-protect-them/

${ }^{32} \mathrm{~A}$ retired long serving bureaucrat of the Madhya Pradesh, and then Chhattisgarh, cadre said that of all the regions of undivided MP, only Chhattisgarh could be said to have had any distinctive identity (Interview, Raipur, August, 2014).
} 
competition between the BJP and the Congress with a conspicuous absence of adivasi parties. The BJP was firmly in command under CM Raman Singh from 2003-2018, and promoted industry and mining vigorously during this period (as discussed in the previous section) $)^{33}$. Tribals have generally been sidelined from top leadership positions (the exception being Congress CM Ajit Jogi’s tenure from 2000-2003; Jogi is a non-Christian tribal). Raman Singh and other top political leaders from both parties belong to the upper castes, and merchant and trader communities, many of whom have benefitted from the expanded role of private actors in mining. Exclusion from this political-economic domination by the upper castes has provoked ire amongst the $\mathrm{OBCs}^{34}$. The Congress has swept to power in the last Assembly election in 2018. A powerful and controversial OBC leader Bhupesh Baghel has been appointed CM in what is widely seen as a move to attract OBC votes, ahead of the national elections in April $2019^{35}$.

Within a political configuration where both parties are locked in tight competition, and without party based political mobilisation of adivasis, Chhattisgarh's extractive regime has lacked as critical an oppositional voice as Jharkhand. On matters of extraction, the Congress has struggled to distinguish itself from the BJP. A top Congress leader in Chhattisgarh remarked that it was unviable for a party to be seen to oppose land acquisition for fear of being labelled 'antidevelopment ${ }^{36}$. In early 2019, the new Congress government in Chhattisgarh has taken the unprecedented decision to return 1700 hectares of land acquired for a \$2.7 billion TATA steel plant back to the tribal families of Bastar. This move comes as a break with the past $\mathrm{t}^{37}$, but could also be seen as a pre-election gimmick by the Congress.

\section{Institutional Effectiveness}

\footnotetext{
${ }^{33}$ A large number of MOUs were signed in Chhattisgarh, leading to allegations of high-level corruption personally implicating the CM. http://www.downtoearth.org.in/news/shah-commission-wound-up-beforeit-could-probe-illegal-mining-in-chhattisgarh-42670

${ }^{34}$ https://www.firstpost.com/politics/chhattisgarh-why-raman-singh-should-take-the-obc-stir-seriously653489.html

${ }^{35} \mathrm{https}$ ://www.huffingtonpost.in/entry/chhattisgarh-cm-bhupesh-baghel-is-a-surprisingchoice in 5c1893fee4b0432554c397c0

${ }^{36}$ Interview, Raipur, July 2015.

${ }^{37} \mathrm{https}$ ://indianexpress.com/article/india/chhattisgarh-bastar-bhupesh-baghel-tata-steel-farmers-5508403/
} 
In this section, we turn to the question of whether the political enablement of bureaucratic capacity can explain how 'effectively' extraction is pursued in these two states (Geddes, 1994; Hickey, 2013; Centeno, Kohli and Yashar, 2017). In quantitative terms such as production and royalty collection as a percentage of targets set by the centre, Jharkhand and Chhattisgarh are not too far apart (see section 2). Even on the notorious 'ease of doing business index' ${ }^{38}$, Jharkhand and Chhattisgarh were clubbed under the 'aspiring leaders' category, ranked three and four respectively ${ }^{39}$. However, beyond these ranks, a general assessment of the business "environment" and status of rules, there are a complex set of relationships that introduce policy and company level variability and uncertainty (Hallward-Driemeier and Pritchett ${ }_{2} 2015$ ). This uncertainty creates a space for 'deals' (in the broad sense of processes and relationships), where the two states are qualitatively different.

Jharkhand's early years were sullied by a particularly inexperienced political leadership and a factionalised bureaucracy. Besides a poor policy base inherited from Bihar, relationships between the incoming political leadership and bureaucratic officials started on a fractious note, producing cliques rather than a coherent cadre. 'Backbencher politicians' suddenly found themselves in charge of a new state, there was no clear dominant leader, and none had any administrative experience. Many members of the new administration proved that they 'were more seasoned and experienced in politicking than the politicians themselves, schooling them to make money through files, tenders and appointments ${ }^{40}$. This set the tone for apathetic institutional functioning, neglecting basic administrative and monitoring procedures within the bureaucratic departmental hierarchy ${ }^{41}$. Moreover, the high turnover of politicians in office was reflected in high transfer rates, and no steady group of bureaucrats at the helm, with a few exceptions who managed to craft their continued favour. Transfers in the mines and industries department were amongst the most frequent in the new state. Our research shows that, on an average, the mines and industries secretaries did not last for more than 10 and 8 months

\footnotetext{
${ }^{38}$ World Bank, DIPP 2015.

${ }^{39}$ Department of Industrial Promotion and Policy, Government of India website

${ }^{40}$ Interview, senior bureaucrat, Ranchi, 2014. This bit of text has been paraphrased from a much a longer interview.

${ }^{41}$ Multiple interviews, Jharkhand's civil servants, Ranchi, August and November 2014, May, 2015.
} 
respectively between 2000 and 2014. The national average for an IAS officer's tenure in one post is 16 months (Iyer and Mani, 2012).

There were considerable administrative challenges in the new Chhattisgarh too. Unlike Jharkhand, where officials were actually happy to join the new cadre to 'escape' from the Laloo Raj, Chhattisgarh was seen by officials as remote and a banishment from the comfortable and well governed Bhopal (capital of MP) ${ }^{42}$. The new cadre of the IAS lacked enough officials of appropriate seniority too. Nevertheless, officials rallied under the leadership of Jogi, a controversial politician but an adroit administrator. The first Finance Secretary of Chhattisgarh described how the CM Ajit Jogi directed the newly minted Chhattisgarh cadre of the IAS to pursue a clear administrative vision for the state ${ }^{43}$. This included the division of the state administrative cadres in 2 years (Jharkhand took 4), and the institution of good practices like regular review meetings and monitoring procedures, and the staffing of line departments ${ }^{44}$. The ensuing tenure of a single Chief Minister (Singh) over the next 15 years, who tightly controlled the mining and industry portfolio, meant that the political leadership's ties to a small group of favoured bureaucrats were cemented over time. This created conditions for greater internal coherence within the bureaucracy even as power was increasingly centralised. These contrasts had serious implications for the institutional effectiveness of extraction, as evidenced in two critical areas: land acquisition and the control of illegal mining.

Land acquisition has had to face many hurdles in Jharkhand because of extended policy stasis and poorly institutionalized systems and processes to facilitate industrial development for many years. Jharkhand inherited a weak industrial policy base from Bihar, but the political situation in the newly created state ensured that after 2001, no new industrial policies were announced for over a decade. The state had no land bank until 2015, despite this finding mention in the two industrial policies of 2001 and later in 2012. It had no updated land records since state formation; even revenue maps were only handed over by Bihar very recently ${ }^{45}$. It also had no clear

\footnotetext{
${ }^{42}$ Interviews, retired MP and Chhattisgarh cadre bureaucrats, New Delhi and Raipur, 2015.

${ }^{43}$ Interview, Raipur, August 2014.

${ }^{44}$ Interview, retired IAS official, Raipur, November 2014.

${ }^{45} \mathrm{http}$ ://indianexpress.com/article/india/india-news-india/revenue-maps-raghubar-das-lashes-out-atnitishkumar-babulal-marandi-2835263/
} 
rehabilitation and resettlement policy until $2015^{46}$, creating an ambiguous situation for land acquisition. The state's bureaucracy has been notorious for slow moving files and held up environment clearances earning a reputation as a state with 'inertia' and multiple disparate demands for rents ${ }^{47}$. As a representative of a prominent association of industries ${ }^{48}$ remarked “industry does not get much support here. Priorities change every time government changes and this leads to instability in the economy. Chhattisgarh has overtaken us because its leadership has a vision for growth. Industry is suffering here". A CAG report has concluded that Jharkhand signed MOUs worth $\$ 52$ billion between 2001 and 2016, but only 3.8 per cent translated into reality ${ }^{49}$. Ironically, this state of affairs has not turned out to any advantage for tribals facing land dispossession, with ample irregularities and the blatant misuse of pro-tribal land laws (Sundar, 2007).

In contrast, the Chhattisgarh government took concerted steps to effectively institutionalise the facilitation of extraction. Singh was closely involved as the Chairman of the State Investment Promotion Board (SIPB) that reviews applications for big projects in excess of $\$ 15$ million. There have been regular iterations of the industrial policy, a functioning single window clearance mechanism and a digitised land records database in place in the state. An official from Jindal Steel $^{50}$ said "the local administration fully supports us. We both make compromises but when land is needed, they immediately get it for us". While Chhattisgarh signed 19 leases for coal and 9 for iron ore between 2000 and 2015, whereas Jharkhand signed 10 and 2 respectively ${ }^{51}$. Unlike Jharkhand, a more proactive state government has used its top bureaucrats for lobbying in New Delhi to expedite central clearances ${ }^{52}$.

Chhattisgarh has aggressively encouraged new private thermal power producers, promising free electricity in exchange for benefits like the arrangement of land by the Chhattisgarh State

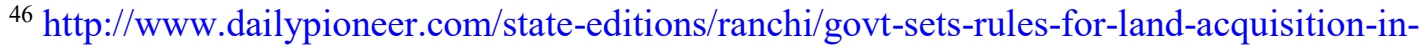
jharkhand.html

${ }^{47}$ Interview, mining reporter, New Delhi, July 2015.

${ }^{48}$ Interview, Ranchi, July 2015

${ }^{49} \mathrm{http}$ ://www.business-standard.com/article/news-ians/jharkhand-failed-to-retain-investors-due-to-poorlaw-and-order-cag-117081300300 1.html

${ }^{50}$ Interview, Raigarh, June 2015

${ }^{51}$ www.ibm.in

${ }^{52}$ Interview, retired IAS official, Raipur, August 2016. Also see CSE (2012, 123).
} 
Industrial Development Corporation. The well-rehearsed official narrative was to make Chhattisgarh 'power surplus'. And yet, most entrants did not have sector expertise. More than 60 power plants were planned after 2005, but barely 15 will come up ${ }^{53}$. Intractable problems from coal block allocation to local resistance were also to blame. This suggests that Chhattisgarh, while demonstrating relatively greater effectiveness at dealing with industry needs around land than Jharkhand, is not immune to the difficulties stemming from land acquisition in the rest of the country.

Another critical area of institutional effectiveness around extraction is the curtailment of smallscale illegal mining. Lahiri-Dutt shows that much illegal mining is an aspect of 'everyday rural life' within large stretches of coal bearing tracts in eastern India, and needs to be viewed as an integral element of the risky, informal economy around mining (2014b, 40). While we cannot generalise from a single case or two, our fieldwork suggests that there are differences in how the two states address small-scale illegalities, which further resonate with their respective levels of institutional effectiveness. The atrophied bureaucratic structure of Jharkhand resulted in inadequate police personnel and forest guards, limiting the government's ability to effectively curb the widely prevalent informal/illegal mining. During fieldwork in Hazaribagh district, we observed that coal smuggling on bicycles under the cover of the night is still common around coal mining areas, and illegal crushers dot the terrain around iron and manganese ore mines in the state. There is little doubt that illegal mining takes place with the tacit support of authorities, but inadequate frontline functionaries that act against such operations is also key.

\section{[INSERT Table 3]}

The proportion of vacancies per sanctioned posts in line departments in Jharkhand has endured much longer than in neighbouring Chhattisgarh, where more efforts have been made to sanction and fill new posts (see Table 3). As a result, local district administrations in Chhattisgarh has been remarkably proficient with clamping down on small scale informal/illegal mining. During fieldwork in Raigarh and Korba districts of Chhattisgarh, respondents both within and outside

\footnotetext{
${ }^{53} \mathrm{https} / / /$ economictimes.indiatimes.com/industry/energy/power/chhattisgarh-power-boom-that-never-wasonly-15-out-60-thermal-plants-may-get-operational/articleshow/16946524.cms
} 
the administration were of the view that small scale illegal mining (like in Jharkhand), which they termed "chhoti chori" or "small theft", largely didn't exist. Several respondents contrasted coal theft on cycles versus coal theft by "dumpers", indicative of the difference in the scale of illegal mining.

Small-scale illegal/informal mining that sustains the livelihoods of very poor people can perhaps be distinguished from higher stakes illegal mining that bears the potential of earning money by wealthier and more influential stakeholders. These include public and private mining companies, transporters, mafia, the police and government functionaries at various levels. Vaishnav (2017) amongst others has documented the extraordinary rise of 'extractive rents' since the early 2000s, as a specific form of 'grand corruption' (that involves high level elected officials with significant political and economic outcomes). At the topmost levels, extractive rent seeking involves the discretionary allocation of public resources (like coal blocks) to private (and other public) players (Vaishnav, 2017). More generally, the rampant transgression of mining rules is a phenomenon that is observed countrywide: mining outside the leased area, mining without environment clearances, mining beyond the lease period and so on are all widely observed and reported, and Jharkhand and Chhattisgarh are no exception. Although we did not directly research these aspects, it is known that while the centrally appointed Shah Commission (that probed illegal mining of iron ore and manganese) conducted its enquiries in Jharkhand with damning conclusions (amongst other states including Odisha, Goa, Karnataka), it was allegedly 'stymied' from conducting investigations in Chhattisgarh. Various civil society actors like the CBA have campaigned publicly against the state and central governments' roles to side with industry in silencing the commission ${ }^{54}$. We revisit the point about the dynamics of resistance next.

To summarise, the extractive regimes of Jharkhand and Chhattisgarh since 2000 have been marked by perceptible differences relating to bureaucratic organisation, capacity and levels of institutionalisation, with Chhattisgarh presenting a more cohesive and enabling state apparatus so far. More recent developments have seen Jharkhand's BJP government take an extremely pro-

\footnotetext{
${ }^{54} \mathrm{http}$ //www.downtoearth.org.in/news/shah-commission-wound-up-before-it-could-probe-illegalmining-in-chhattisgarh-42670
} 
industry stance, as witnessed in the recent forcible acquisition of land for the Adani group ${ }^{55}$, showing the intensification of the regime's penchant for repression and manipulation. This takes us to the final dimension of the extractive regime.

\section{Nature and Management of Resistance}

Following on from the rich legacy of the statehood movement in Jharkhand, and its conspicuous absence in Chhattisgarh, there is a more vibrant and plural presence of social activism and resistance in the former as compared to the latter. The far more fragmented political landscape and the multiplicity of adivasi political parties that lack centralised political party cultures in Jharkhand appear in stark contrast to Chhattisgarh, where the long staying dominant BJP has been tightly run by a central command. The relatively more cohesive extractive regime in Chhattisgarh has come down heavily and in a concerted manner to restrict the space for dissent. State leadership has changed only very recently with the Congress victory in Chhattisgarh in 2018, and it is still too early to judge the impact that this will have.

Violent resistance to extraction in the form of left wing extremism has gripped both Jharkhand and Chhattisgarh, though its presence is featured by greater dispersal across Jharkhand as compared with Chhattisgarh where the southern districts experience intense activity. Left wing extremists or 'Naxals' have waged a long struggle against state sponsored and corporate backed mining and industrialisation, especially in the wake of economic liberalization in the early 1990s and state creation in 2000 (Kennedy, 2014; Sundar, 2016). Jharkhand's crackdown on Maoists is a weak parallel to Chhattisgarh which has taken a notoriously hard line by promoting a vigilante army called 'Salwa Judum' (or purification hunt) in 2005 (Sundar, 2016). The Salwa Judum, backed by both Congress and BJP, is a good illustration of the close compact between the top political and economic elites along with police and security forces (see Miklian, 2009).

Moreover, Jharkhand has a large and very active network of social movement organisations which have been resisting mining in the state and fighting to secure indigenous rights to land and

\footnotetext{
${ }^{55} \mathrm{https}$ :/www.indiaspend.com/taking-over-fertile-land-for-adani-group-from-protesting-farmersjharkhand-government-manipulates-new-law-meant-to-protect-them/
} 
resources. A leading social activist and Christian missionary who galvanised anti-displacement forces under different umbrella organisations, recounted how even when the centrally initiated Operation Green Hunt ${ }^{56}$ took place in Jharkhand in 2011, a massive protest was organised here ${ }^{57}$. It is worth emphasising that it was a BJP led government that was in power in Jharkhand between 2010 and 2013 when this 'operation' took place. The Jharkhand Mines Area Coordination Committee (JMACC), a prominent alliance of mining affected communities, has raised the visibility of irregularities and human rights violations through fact finding reports of police firings, organised citizen tribunals and the demand for compensation. Although local in nature, this alliance also has strong links to national and transnational organisations such as Amnesty International.

Interviews with elected leaders and civil society groups indicate that resistance activities do get local political support, which in some cases have been escalated to the state level and raised in the legislative assembly. For example, in Hazaribagh, one of our study districts we found the state's former agriculture minister, who is from the Congress party, lending strategic support to a long standing agitation against a national thermal power company. Both the administration and mining company officials in separate interviews pointed to the significant role this Minister's intervention has played in stalling the project for eleven years. The General Manager of the thermal power company exclaimed with much exasperation that this minister "is keeping the whole machinery and the state to ransom.....we tried through the Ministry of Coal and the Ministry of Power in the Congress-led national government to get our project pushed, but nothing happened"s8.

In 2016, when amendments to customary land laws were being debated in the state legislative assembly, which would ease land acquisition for industry more generally and mining interests in particular, the Jharkhand Mukti Morcha (JMM) organised akrosh rallies or 'demonstrations of anger'. In a press conference, the leader of the JMM stated- 'The State Government is conspiring to grab lands of innocent tribals and handing it over to big industrial houses.... both land acts are

\footnotetext{
${ }^{56}$ A so-called all out offensive by the Indian government to tackle and 'weed out' the Naxal challenge in states along India's 'red corridor'.

${ }^{57}$ Interview, Ranchi, August 2014.

${ }^{58}$ Interview, Hazaribagh, Jharkhand
} 
the essence of the tribal and indigenous people of the State ${ }^{59}$. Fierce resistance by opposition parties including some ruling party members ${ }^{60}$ has pushed the Cabinet to withdraw amendments and attempt to build cross-party consensus.

There is no comparable legacy of social movements in Chhattisgarh (with the exception of Bastar's rich history of popular mobilisation). The influence of the two main sources of civil society action: the Chhattisgarh Mukti Morcha (CMM) which is a trade union movement from the 1970s and the Ekta Parishad which is a pan Indian grassroots activist movement - have both waned over time. Their various offshoot and affiliate bodies have suffered the harsh consequences of successive state crackdowns, especially with the rise of left wing extremism in the state since the 1990s. The Chhattisgarh Bachao Andolan, a non-profit organisation, continues to forge solidarity amongst smaller organisations within the state and is well connected nationally and internationally. However, given the climate of oppression, it has not produced large-scale civil society mobilization that can effectively challenge the two dominant parties. During fieldwork in Korba and Raigarh, we observed very limited political support for resistance. Local politicians closely stick to the party line and are tightly controlled by the statelevel committees of the two national parties (BJP, Congress) that dominate electoral politics.

Our research has shown that the outcomes of resistance struggles are extremely varied, depending on a configuration of local political negotiations, and any 'concessions' that might be made in the form of employment or compensation are 'company specific' ${ }^{\prime 61}$. One common response in both states though, is the attempted suppression of resistance by the state branding civil society resistance activities as Maoists. According to a study published by a civil rights activist we interviewed, 97\% per cent of the 102 undertrials accused of being Maoists or Maoist sympathisers and then booked under Unlawful Activities Prevention Act (UAPA) in Jharkhand are dalits and adivasis who earn less $\$ 70$ a month (Bagaicha 2016). Despite its

\footnotetext{
${ }^{59} \mathrm{http} / / /$ www.dailypioneer.com/STATE-EDITIONS/ranchi/jmm-protests-against-move-to-amend-landlaws.html

60 'Jharkhand tenancy Acts: 2 amendments withdrawn, CM calls for broad-based talks', Indian Express, 5 July 2017

${ }^{61}$ We studied the district level operations of the two Coal India operations (public sector) in the two states, and the Tata and Jindal companies (private sector). These are beyond the scope of this paper, and will be presented elsewhere.
} 
more diverse culture of social and political resistance and fragmented state response, many activist informants attested to increasing state repression in Jharkhand, especially since 2014.

The involvement of elected representatives moreover is not an adequate safeguard against violent state retaliation however. Even in the case of the thermal power plant with an elected minister leading a part of the demonstrations, police firings were used to deal with protestors ${ }^{62}$. Data from the South Asia Terrorism Portal of numbers for arrests of Maoists/Left wing extremists over 10 years since 2005 shows an increase in both states, even though the number has been higher in Chhattisgarh since $2013^{63}$. Beyond the direct containment of Maoist violence, the Chhattisgarh government's Mission 2016 has also been associated with mounting pressures on lawyers that take up cases on behalf of tribal prisoners in the state, many of whom are labelled Maoists ${ }^{64}$. The rise of corporate media and newspapers is another enabling factor in marginalising dissenting viewpoints, especially in Chhattisgarh. This state, with its relatively more cohesive institutional apparatus and a unified political dispensation, backs concomitantly harsher crackdowns on resistance to mining than is the case in Jharkhand. However, under the current BJP government, Jharkhand is mirroring Chhattisgarh much more in terms of the impunity with which the state is dealing with resistance.

\section{CONCLUSION}

This article has been written as a part of the wider ongoing interest in the multilevel politics of extraction, with the subnational emerging as a critical domain of study. India has substantial insights to offer because it is a country where mining is historically important, and where the creation of two new mineral rich states, Jharkhand and Chhattisgarh, has been an unprecedented move that has intensified mineral based politics. The main contribution of the article lies in exploring the role of subnational territorial reorganisation as a critical juncture producing the ideological, institutional and political conditions enabling extraction in the two states but in

\footnotetext{
${ }^{62} \mathrm{http} / / / \mathrm{www} \cdot$ thehindu.com/todays-paper/tp-opinion/why-the-land-wars-wont-end/article5183838.ece

${ }^{63} \mathrm{http}: / / \mathrm{www}$. satp.org/satporgtp/countries/india/maoist/data_sheets/annualcasualtieschhatisgarh.asp; http://www.satp.org/satporgtp/countries/india/maoist/data_sheets/anl_cas_jh.asp

${ }^{64} \mathrm{http}$ ://thewire.in/12482/in-chhattisgarh-pressure-mounts-on-lawyers-taking-up-cases-of-tribal-prisoners/
} 
different ways. This focus is inspired by the rather dissimilar experiences of the two states, despite comparable mineral and human development profiles, in the nearly two decades since 2000. Drawing closely upon these experiences, and going well beyond the resource curse literature, the article presents a theorisation of their 'extractive' regimes along three analytical dimensions: political history and organisation, institutional effectiveness, and the nature and management of resistance. Each of these is related to state formation, with an exploration of how Jharkhand and Chhattisgarh vary along these, and to what effects.

Jharkhand's strong adivasi movement for resource rights and statehood gave way to a highly fragmented electoral space which saw a multiplicity of adivasi parties compete predominantly with the BJP, leading to short lived coalition governments until 2014, after which the BJP has commanded majority. In Chhattisgarh, there was no comparable movement, only a tenuous link with resource identity, and neither of the two higher caste led main political parties (BJP and Congress) allowed for any significant adivasi representation. The article analyses how these conditions allowed for a more complex public discourse around extraction in Jharkhand, with political leaders feeling the pressure to proclaim the sacrosanct nature of adivasi resource rights, even as they presided over extraction, with widespread rent-seeking. In Chhattisgarh, the long stay of the BJP has been conducive to the making of a firm public commitment to advance extraction, and high level association with extractive rents, with the Congress generally unable to provide an effective critical oppositional voice.

In Jharkhand, statehood shaped the relationship between the inexperienced political leadership and the factionalised bureaucracy. The short turnover of governments led to indiscriminate rent seeking by both politicians as well as bureaucrats, and a highly apathetic attitude towards the improvement of institutional state capacity (like by filling up vacancies), or prioritisation of institutional reform (like by putting in place monitoring and review mechanisms for governmental functioning). In Chhattisgarh, the main leaders after state creation, Jogi and Singh, were secure in their status, politically astute, and encouraged a core group of bureaucrats to pursue institutional capacity building and reform as state priorities. Key bureaucrats cohesively pursued these objectives, in a manner that was strikingly different from Jharkhand. The article discusses how these contrasts produced different results in the key arenas of extraction: land 
acquisition and the control of illegal mining. However, it needs to be emphasised that Chhattisgarh was only relatively more effective than Jharkhand as an extractive regime, exhibiting a degree of dysfunctionality due to larger nation-wide problems with land acquisition and the cancellation of coal block allocations.

Following on from its social movement legacy, Jharkhand has had a much stronger and politically engaged network of resistance to mining than Chhattisgarh. A large number of civil society organisations, often with active support from local political representatives from JMM, other adivasi parties and the Congress, have been resisting mining. Despite the lack of a similar legacy, there have been brave attempts to resist mining in Chhattisgarh too, stemming from the influence of two key networks (CMM and the CBA), but there are two main differences. First, a relatively more cohesive state apparatus under a relatively more unified political dispensation has been institutionally more effective with suppressing mining in Chhattisgarh as compared to Jharkhand, though there have certainly been many attempts at repression in the latter too. Second, fewer elected political representatives support resistance here, sticking to the party line in most cases. Chhattisgarh has definitely come down with a much firmer hand on violent 'Maoist' resistance than has Jharkhand, and while there are alarming increases in the number of arrests of those branded as Maoist, the number is greater in Chhattisgarh.

While considering more recent developments since 2014, the election of the BJP as a majority party in Jharkhand appears to be triggering some important changes in the nature of the extractive regime, bringing it closer to Chhattisgarh, a state that has largely been under dominant BJP rule since state creation. For the first time, Jharkhand- whose fragmented political competition has been its hallmark- has a majority government, which is remarkably producing a much more brazen and repressive pursuit of extraction than before. The political orientation of this majority party (the BJP) is highly relevant to this turn of developments, where we find the two states developing more convergences than differences (the recent election of the Congress in Chhattisgarh will need to be observed closely). Nevertheless, resistance by regional parties to anti-tribal legislative changes which are intrinsically tied to the interests of extractive industries, remains important in Jharkhand. 
While these convergences manifest more clearly in the first and third dimensions of the extractive regime (public discourse on extraction, and the suppression of resistance), these are less easily evident with respect to the second dimension (institutional effectiveness). Institutional change is undoubtedly a bigger challenge than policy reform, but Jharkhand has made strides in expediting extraction (like developing a competitive business environment including the single window clearance mechanism earning it a top rank in the country ${ }^{65}$. The change of party in charge (from BJP to Congress in Chhattisgarh), but not the broad character of political competition, will need to be closely assessed for its implications in the coming years. In conclusion, while the recent convergences in two states that started out so differently nearly two decades ago may be a sign of greater homogenisation of the political space, the powerful legacy of a statehood movement in one state and its absence in the other combined with complex divisions in subnational democratic politics continues to lend a distinctive character to the extractive regimes in the two states.

${ }^{65} \mathrm{https}$ ://www.advantage.jharkhand.gov.in/SingleWindow/ 


\section{References}

Acemoglu, D. and J. Robinson (2012). Why Nations Fail: The Origins of Power, Prosperity and Poverty. New York: Random House.

Andersen, J. J., \& Ross, M. L. (2013). 'The Big Oil Change', Comparative Political Studies 47(7): 9931021

Arsel, M., Hogenboom, B. Barbara and L. Pellegrini (2016). The extractive imperative in Latin America. Extractive Industries and Society, 3(4): 880- 887.

Auty, R. (1993), Sustaining Development in Mineral Economies: The Resource Curse Thesis. Routledge.

Basu, I. (2012). 'The politics of recognition and redistribution: Development, tribal identity politics and distributive justice in India's Jharkhand', Development and Change, 43(6): 1291- 1312.

Bagaicha Research Team (2016) Deprived of rights over natural resources, impoverished adivasis get prison: A study of undertrials in Jharkhand. Ranchi: Bagaicha Trust

Bebbington, A. (1996). 'Movements, modernizations, and markets: indigenous organizations and agrarian strategies in Ecuador', in R. Peet and M. Watts (eds) Liberation Ecologies: Environment, Development, Social Movements, pp. 86-109. Routledge, London.

Bebbington, A. (2012). Social conflict, economic development and extractive industry: Evidence from South America. London: Routledge.

Bebbington, A. (2013) 'Natural resource extraction and the possibilities of inclusive development: Politics across space and time', ESID Working Paper 21. Manchester: University of Manchester.

Bebbington, A., L. Hinojosa, D. H. Bebbington, M. L. Burneo and X. Warnaars (2008) 'Contention and Ambiguity: Mining and the Possibilities of Development' Development and Change, 39 (6): $887-$ 914 
Bebbington, A., A-G. Abdulai, D.H. Bebbington, M. Hinfelaar and C. Sanborn (2018) Governing Extractive Industries: Politics, Histories, Ideas. Oxford: Oxford University Press

Berthet, S. (2011) 'Chhattisgarh: Redefining the Role of the State?', in Eds. S. Berthet and G. Kumar, (eds) New States for a New India: Federalism and Decentralisation in the States of Jharkhand and Chhattisgarh, pp. 87-115. New Delhi: Manohar Publishers..

Bo Nielsen, K. and A.G. Nilsen (2017) 'Law struggles, law-making and the politics of hegemony in neoliberal India: Towards a critical perspective on the 2013 Land Acquisition Act', in A.P. D'Costa and A. Chakraborty (eds) The Land Question in India: State, Dispossession and Capitalist Transition, pp. 129-150. Oxford: Oxford University Press.

Bridge, G. (2004). Contested terrain: Mining and the environment. Annual Review of Environmental Resources 29: 205-259.

Bridge, G. 2013. Resource geographies II: the resource-state nexus. Progress in Human Geography 38 (1): 118-130.

Bhattacharjee, S. (2017) India's Coal Story: From Damodar to Zambezi. Sage Publications.

Centeno, M. A., Kohli, A., Yashar, D. J (2017) Unpacking States in the Developing World: Capacity, Performance and Politics, in M.A. Centeno, A. Kohli, D.J. Yashar and D. Mistree (eds) States in the Developing World. Eds, pp 1-31. Cambridge: Cambridge University Press.

Centre for Science and Environment (2008) Rich Lands, Poor People: Is Sustainable Mining Possible? State of India's Environment: A citizens' report, No. 6, New Delhi.

Chakraborty, L., Garg, S., \& Singh, G. (2016). Cashing in on Mining. NIPFP Working Paper 16/161. New Delhi: National Institute of Public Finance and Policy.

Chakravorty S. (2003) Industrial location in post-reform India: patterns of inter-regional divergence and intra-regional convergence, Journal of Development Studies 40:120-52. 
Chandra, R. (2018) ‘Adaptive State Capitalism in the Indian Coal Industry’. PhD. Dissertation, Harvard University, USA.

Chaudhury, M. (2015) 'Fiscal parameters of Jharkhand and Chhattisgarh: A comparison'. Working Paper, New Delhi: National Institute of Public Finance and Policy.

Conde, M. (2017) ‘Resistance to Mining: A Review’, Ecological Economics, 132: 80-90.

Corbridge, C. (1987). 'Perversity and ethnoregionalism in tribal India: The politics of India's Jharkhand', Political Geography Quarterly 6(3): 225-240.

Corbridge, C. (2002) ‘The continuing struggle for India's Jharkhand: Democracy, decentralization and the politics of names and numbers', Commonwealth and Comparative Politics, 40(3): 55-71.

Damodaran, V. (2006) 'The politics of marginality and the construction of indigeneity in Chota Nagpur', Postcolonial Studies 9(2): 179-196.

D'Costa, A.P. and A. Chakraborty (eds) (2017). The Land Question in India: State, Dispossession and Capitalist Transition. Oxford: Oxford University Press.

Di John, J. (2009). From Windfall to Curse? Oil and industrialisation in Venezuela, 1920-present. Pennsylvania: Pennsylvania University Press.

Dhillon, A., P. Krishnan, M. Patnam, and C. Perroni (2016) 'The Natural Resource Curse Revisited: Theory and Evidence from India'. Competitive Advantage in the Global Economy (CAGE) Working Paper. Warwick: CAGE

Fearon, J. D. and D.D. Laitin (2003) 'Ethnicity, insurgency, and civil war' American Political Science Review 97(1): 75-90.

Forest Survey of India (2013) State of Forest Report. New Delhi: Ministry of Environment and Forests, Government of India. 
Geddes, B. (1994). Politician's Dilemma: Building State Capacity in Latin America. Berkeley: University of California Press.

Ghosh, S. (2006) 'Demystifying the environmental clearance process in India', NUJS Law Review 3 ( July-September).

Gilberthorpe, E. and E. Papyrakis (2015) 'The extractive industries and development: The resource curse at the micro, meso and macro levels', The Extractive Industries and Society, 2(2): 381-390.

Harvey, D. (2003) The New Imperialism. Oxford: Oxford University Press.

Hallward-Driemeier, M., and L. Pritchett (2015) 'How Business Is Done in the Developing World: Deals versus Rules', Journal of Economic Perspectives, 29(3): 121-140.

Hickey, S. (2013). Thinking about the politics of inclusive development: Towards a relational approach. ESID Working Paper no. 1, Manchester: University of Manchester.

Hickey, S. and A. Izama (2017) 'The Politics of Governing Oil in Uganda: Going against the Grain' African Affairs, 116 (463): 163-185.

Horowitz, L. S. (2012) 'Translation Alignment: Actor-Network Theory, Resistance, and the Power Dynamics of Alliance in New Caledonia’, ANTI Antipode, 44(3): 806-827.

Humphreys-Bebbington, D. and A. Bebbington (2012) 'Post-What? Extractive Industries, Narratives of Development, and Socio-Environmental Disputes across the (ostensibly changing) Andean Region', in H. Haarstad (ed) New Political Spaces in Latin American Natural Resources Governance, pp. 17-37. London: Palgrave Macmillan.

Isham, J., M. Woolcock, L. Pritchett and G. Busby (2005) 'The Varieties of Resource Experience: Natural Resource Export Structures and the Political Economy of Economic Growth' World Bank Economic Review, 19(2):141-174.

International Energy Agency (2015) India Energy Outlook. Paris: IEA. 
Indian Bureau of Mines (2013) Statistical Profiles of Minerals 2013-14. New Delhi: Ministry of Mines, Government of India

Iyer, L., and A. Mani (2012) 'Traveling agents: political change and bureaucratic turnover in India' Review of Economics and Statistics, 94(3): 723-739.

Jaffrelot, S. (2009) 'The Uneven Rise of Lower Castes in the Politics of Madhya Pradesh', in C. Jaffrelot, C. and S. Kumar (eds) Rise of the Plebians? The Changing Face of Indian Legislative Assemblies, pp. 103-150. New Delhi: Routledge.

Kale, S. S. and N. Mazaheri (2014) 'Natural Resources, Development Strategies, and Lower Caste Empowerment in India's Mineral Belt: Bihar and Odisha During the 1990s', Studies in Comparative International Development 49(3):343-369.

Karl, T.L. (2007) 'Ensuring fairness: the case for a transparent fiscal contract', in M. Humphreys, J. Sachs and J. Stiglitz (eds) Escaping the resource curse, pp. 256-285. New York: Columbia University Press.

Kashwan, P. (2017). Democracy in the Woods: Environmental Conservation and Social Justice in India, Tanzania and Mexico. Oxford: Oxford University Press.

Kennedy, J. (2014) 'Gangsters or Gandhians? The Political Sociology of the Maoist Insurgency in India', India Review, 13(3): 212-234.

Kumar, K. (2014) 'The Sacred Mountain: Confronting Global Capital at Niyamgiri', Geoforum 54: 196-206.

Lahiri-Dutt, K. (2014 a) 'Introduction to Coal in India: Energising the Nation', in K. Lahiri-Dutt (ed) The Coal Nation: Histories, Ecologies and the Politics of Coal in India, pp 1-38. Aldershot: Ashgate. 
Lahiri-Dutt, K. (2014b) 'Between Legitimacy and Illegality: Informal Coal Mining at the Limits of Justice', in K. Lahiri-Dutt (ed)The Coal Nation: Histories, Ecologies and the Politics of Coal in India, pp 39-62. Aldershot: Ashgate.

Levien, M. (2013) 'Regimes of Dispossession: From Steel Towns to Special Economic Zones' Development and Change 44(2): 381-407.

Levien, M. (2015) 'From Primitive Accumulation to Regimes of Dispossession: Six Theses on India's Land Question' Economic and Political Weekly 50(22): 146-157.

Levien, M. (2018) Dispossession without Development: Land Grabs in Neoliberal India. New York: Oxford University Press.

Lieberman, E. S. (2001) 'Causal Inference in Historical Institutional Analysis', Comparative Political Studies, 34(9): 1011-1035.

Marsten, A. and T. Perrault (2017) 'Consent, coercion and cooperativismo : Mining cooperatives and resource regimes in Bolivia', Environment and Planning A, 49(2): 252-272.

Matthew, S. and M. Moore (2011) 'State Incapacity by Design: Understanding the Bihar Story', IDS Working Paper 366. Brighton: Institute of Development Studies.

Mawdsley, E. (2002) 'Redrawing the Body Politic: Federalism, Regionalism and the Creation of New States in India', Commonwealth and Comparative Politics 40 (3): 34-54.

Miklian J. (2009) 'The purification hunt: The Salwa Judum counterinsurgency in Chhattisgarh, India', Dialectical Anthropology, 33(3): 441-459.

Ministry of Coal (2013), Annual Report 2013-14. New Delhi: Ministry of Coal, Government of India Mullick, S.B. (2011) 'Commons to Capital: With a special reference to the Mundas of Jharkhand', Social Change 41(3): 381-396. 
Omvedt, G. (1993). Reinventing Revolution: New Social Movements and the Socialist Tradition in India. New York: Routledge.

Oskarsson, P. (2013) 'Dispossession by confusion from mineral-rich lands in central India', Journal of South Asian Studies, 35(2): 199-212

Padel, F. and S. Das (2010) 'Cultural genocide and the rhetoric of sustainable mining in East India', Contemporary South Asia 18(3): 333-341.

Papyrakis, E. (2017) The Resource Curse - What Have We Learned from Two Decades of Intensive Research: Introduction to the Special Issue. The Journal of Development Studies 53(2): 175-185.

Pellegrini, L. (2018) 'Imaginaries of development through extraction: The History of Bolivian Petroleum and the present view of the future', Geoforum 90: 130-141.

Perreault, T. (2006) 'From the Guerra del Agua to the Guerra del Gas: Resource governance, popular protest and social justice in Bolivia', Antipode, 38(1): 150-172.

Potetee, A.R. (2009) 'Is Development Path Dependent or Political? A Reinterpretation of Mineral Dependent Development in Botswana', Journal of Development Studies 45 (4): 544-571.

Ray, R. and M. F. Katzenstein (2005) 'Introduction: In the Beginning, there was the Nehruvian State', in Raka Ray (ed) Social Movements in India: Poverty, Power and Politics, pp 1-31.USA: Rowman and Littlefield Publishers.

Rights and Resources Institute (2016) 'Land Conflicts in India: An Interim Analysis', RRI Working Paper. New Delhi: Rights and Resources Initiative.

Robin, C. (2009) 'Bihar: The New Stronghold of OBC Politics', in C. Jaffrelot, and S. Kumar (eds) Rise of the Plebians? The Changing Face of Indian Legislative Assemblies, pp. 65-102. Routledge: New Delhi. 
Ross, M. L. (2015) 'What Have We Learned about the Resource Curse?', Annual Review of Political Science 18(1): 239-259.

Singh, P.K. (2008) 'Jharkhand Movement: From Genesis Till Date', in G. K. Bera (ed) The Unrest Axle: Ethno-social movements in Eastern India, pp. 31-74. New Delhi: Mittal Publications.

Sud, N. (2014) 'Governing India’s Land', World Development 60: 43-56.

Sundar, N. (2007) 'Laws, Policies, and Practices in Jharkhand', in N. Sundar (ed) Legal Grounds:

Natural Resources, Identity and the Law in Jharkhand, pp. 1-29. New Delhi: Oxford University Press

Sundar, N. (2016) The burning forest: India's war in Bastar. New Delhi: Juggernaut.

Tillin, L. (2013) Remapping India: New States and their Political Origins. London: Hurst Publishers.

Tillin, L., R. Deshpande and K.K. Kailash (ed) (2015) Politics of Welfare: Comparisons across Indian States. New Delhi: Oxford University Press.

Vaishnav, M. (2017) When Crime Pays - Money and Muscle in Indian Politics. New Haven; London: Yale University Press.

Van Teijlingen, K. (2016) 'The 'Will to Improve' at the mining frontier: Neo-extractivism, development and governmentality in the Ecuadorian Amazon', The Extractive Industry and Society 3(4): 902-911.

Watts, M. (2004) 'Resource curse? governmentality, oil and power in the Niger Delta, Nigeria', Geopolitics 9(1): 50-80. 
Figure 1. Location of Study Sites

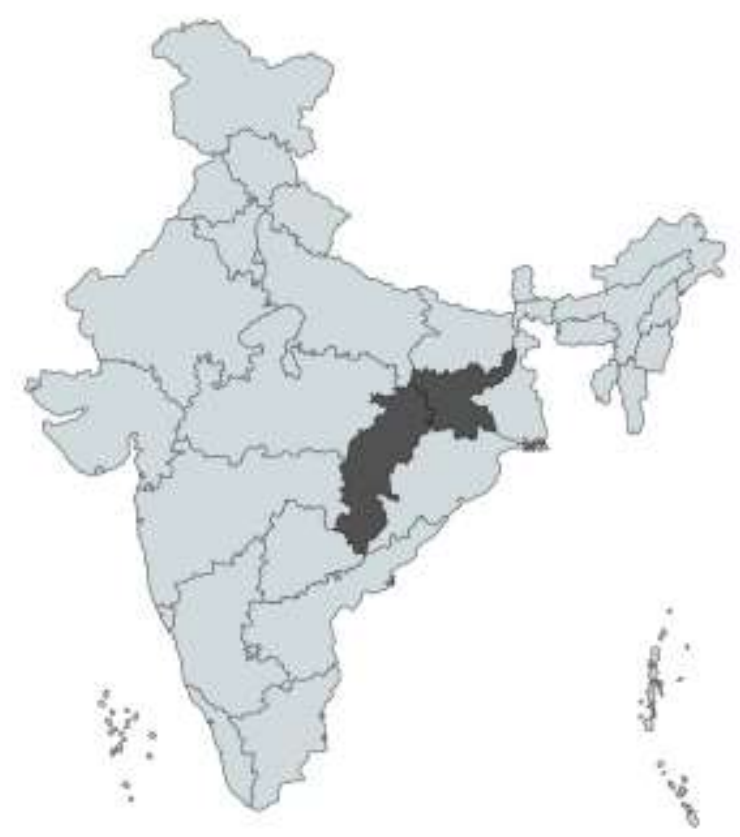

Figure 2. FDI in the Mining Sector (in USD million)

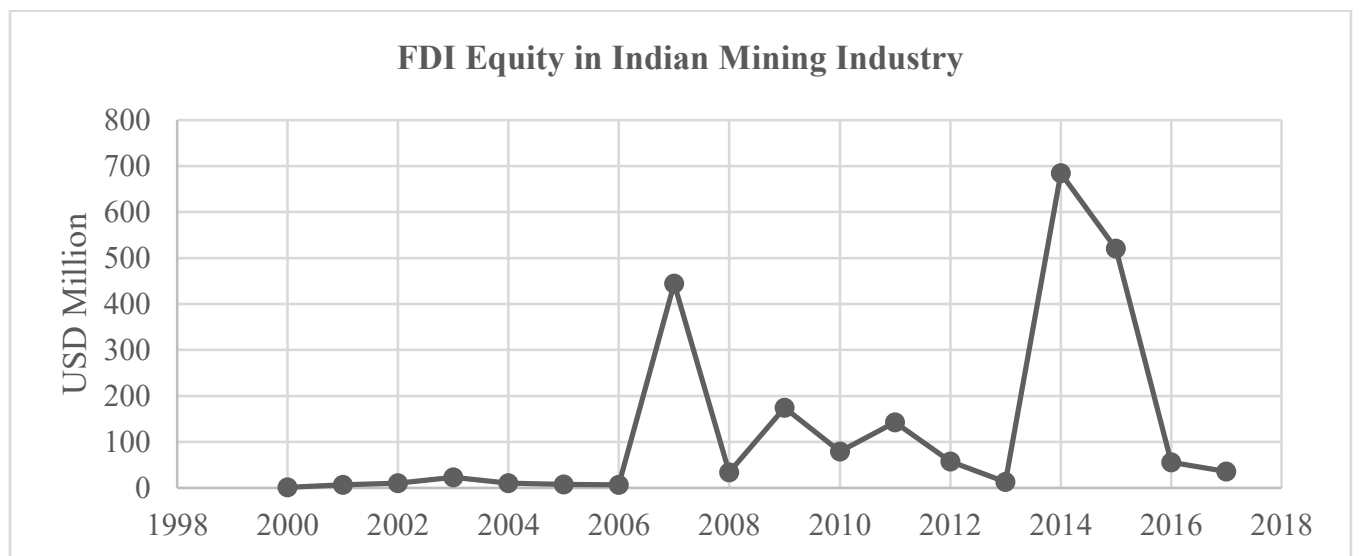

Source: Ministry of Commerce and Industry, Department of Industrial Policy and Promotion, Government of India

Table 1. Socio-Economic and Mineral Profiles of Jharkhand and Chhattisgarh

\begin{tabular}{lcc}
\hline & Jharkhand & Chhattisgarh \\
\hline Population & 32 million & 25 million \\
Population below poverty line (\%) & 37 & 40
\end{tabular}


Tribal population $(\%)$

Literacy rate $(\%)$

Infant mortality rate (per 1000 live births)

Contribution to national coal reserves $(\%)$

Contribution to national Iron ore reserves

$(\%)$

Contribution of mining to GSDP (\%)

Amount of area leased for mining

(hectares)

Source: Census 2011, National Family Health Survey IV (2015-16), Indian Bureau of Mines (2013)
30

71

54

23

18

10

Table 2. The Three Dimensions of the Extractive Regime in Jharkhand and Chhattisgarh

\section{Jharkhand}

Political history and organisation

Political enablement state/bureaucratic capacity institutional functioning

Nature and management of resistance

\section{Chhattisgarh}

Strong adivasi movement for resource rights and statehood; shortlived coalition governments with multiple adivasi parties until 2014; post-2014 BJP majority government of Factionalised bureaucracy pandering and to multiple political elites; poorly institutionalised state mechanisms
No comparable statehood movement; no adivasi political parties; restricted two-party competition between Congress and BJP; BJP in power for 3 consecutive terms until 2018, succeeded by Congress

Cohesive bureaucracy, tightly controlled by dominant political leader; well institutionalised state mechanisms

Dispersed violent Maoist activity, strong network of peaceful antiextraction civil society actors, local political involvement in resistance, fragmented state response of containment, increasingly aggressive and open tackling of resistance
Concentration of violent Maoist activity in southern districts, firm crackdown on anti-extraction resistance, dispersed pockets of peaceful resistance, low political engagement in resistance

Table 3. Department of Industries: Sanctioned and Vacant Posts

\section{Chhattisgarh}




\begin{tabular}{lcccc}
\hline Name of post & $\begin{array}{c}\text { Number of } \\
\text { sanctioned } \\
\text { posts }\end{array}$ & $\begin{array}{c}\text { Number of } \\
\text { vacant posts }\end{array}$ & $\begin{array}{c}\text { Number of } \\
\text { sanctioned } \\
\text { posts }\end{array}$ & $\begin{array}{c}\text { Number of } \\
\text { vacant posts }\end{array}$ \\
\hline Chief GM, DIC & 3 & - & 4 & - \\
GM, DIC & 18 & - & 31 & 2 \\
Manager & 68 & 26 & 80 & 33 \\
Assistant Manager & 102 & 43 & 130 & 55
\end{tabular}

\section{Jharkhand}

As on $1^{\text {st }}$ November 2000

\begin{tabular}{lcccc}
\hline Name of post & $\begin{array}{c}\text { Number of } \\
\text { sanctioned } \\
\text { posts }\end{array}$ & $\begin{array}{c}\text { Number of } \\
\text { vacant posts }\end{array}$ & $\begin{array}{c}\text { Number of } \\
\text { sanctioned } \\
\text { posts }\end{array}$ & $\begin{array}{c}\text { Number of } \\
\text { vacant posts }\end{array}$ \\
\hline GM, DIC & 12 & 0 & 12 & 6 \\
Manager & 36 & 32 & 36 & 36 \\
Assistant Manager & 48 & 38 & 48 & 36
\end{tabular}

